\title{
Critical Commentary: Social Work Ethics ${ }^{1}$
}

\author{
Sarah Banks ${ }^{2}$
}

\section{Abstract}

This short article explores the expanding and contested terrain of social work ethics, considering the form and content of future areas for development. It charts the broadening of the field beyond a focus on professional codes of ethics, principle-based theories, difficult cases and decision-making models towards more embedded and situated approaches to ethics in professional life. The potential for further empirical research into ethical issues in social work, including how practitioners conceptualize and handle ethical difficulties, is noted, alongside the scope for focused studies and monographs drawing on moral, political and religious philosophy to examine particular theoretical approaches (such as virtue ethics or the ethics of care) or to develop new ways of approaching ethics in social work, drawing on its radical, critical and transformatory traditions.

1 Originally published in The British Journal of Social Work, on the $1^{\text {st }}$ September 2008, by the Oxford University Press.

2 Sarah Banks is Professor in the School of Applied Social Sciences, Durham University, UK. 


\section{Introduction}

This critical commentary focuses on social work ethics as an emerging subject area within the professional discipline of social work ${ }^{3}$. In this context, I am using the term 'social work ethics' as a singular term to refer to a specialist area of professional ethics comprising the study of the norms of right action, good qualities of character and values relating to the nature of the good life that are aspired to, espoused and enacted by social workers in the context of their work.

The body of literature on social work ethics is still relatively small compared with that in related fields such as medical or nursing ethics, but it is rapidly growing. There are several reasons for this expansion, including the continuing professionalization of social work and the establishment of new and longer higher education programmes in many countries across the world. This is resulting in a growth of social work literature generally and the emergence of specialist areas of knowledge for research, teaching and practice, of which social work ethics is one.

Social work ethics is also being influenced by the same global trends that are creating 'applied ethics' as a topical subject area. High-profile environmental, medical, scientific and socio-political issues such as climate change, developments in genetic technologies and global terrorism are bringing to the fore new versions of perennial ethical questions about human responsibilities, the nature and value of human and animal life and social justice in the recognition of diversity and distribution of scarce resources. These factors influence the context in which social work is practised and theorized.

The 'postmodern' turn in sociological and philosophical thinking has contributed to a questioning of universal values, all-embracing foundational theories (including ethical theories) and the legitimacy and roles of 'expert' professional practitioners in relation to service users. There has also been a heightened concern to monitor and manage risk in social welfare work; a restructuring of welfare systems in many countries; the introduction of mechanisms for surveillance and control of citizens and service users; and increasing regulation of the work of professional practitioners.

3 The critical commentary is not designed to offer an historical or comprehensive overview of relevant literature on social work ethics - good lists of references can be found in the many recent textbooks on the subject, such as Reamer (2006), Black et al. (2002, with a revised version due shortly), or Banks (2006). Rather, it selects some examples of different types of published work, with an emphasis on recent English-language publications, with the aim of considering the current state of the field and the potential for future development. 
These factors are contributing to a continuing concern with professional power, legitimacy, credibility, conduct/misconduct and a questioning of the traditional professional-client relationship-all themes that fall within the scope of social work ethics.

This expansion in the field of social work ethics clearly involves an increase in quantity of literature published and in the amount of time spent on the subject in professional education. There is also an expansion in the forms of literature comprising the corpus of work on social work ethics-going beyond the traditional professional codes, ethical guidelines, textbooks and scholarly articles, to include empirically based articles, with signs of potential for more specialist texts and research monographs. Finally, the expansion includes a broadening of the substantive content of the social work ethics literature and teaching curricula to include not just principle-based theories of ethics, but also virtue-, care- and narrative-based approaches; to include descriptive as well as normative ethics; and a focus on ethics in social work research as well as in social work practice.

In this paper, I will discuss briefly the expansion of social work ethics using the three headings identified above. I will not specifically cover ethics in social work research (although this is certainly relevant, particularly with the growth of practitioner research), as this is a rapidly expanding and complex area, worthy of consideration in its own right (see, e.g. Antle and Regehr, 2003; D'Cruz and Jones, 2004).

\section{Quantity: the 'ethics boom'4}

One indicator of the growth of interest in social work ethics is the recent introduction of two specialist journals: The Journal of Social Work Values and Ethics (a USA-based electronic open access journal with a specific focus on social work launched in 2005) and Ethics and Social Welfare (a British-based subscription journal launched in 2007 with a broader focus covering ethics in social policy and the social professions, but with a strong emphasis on social work). The small core of student text-books on social work ethics, which started to develop in the 1980s, grew significantly in the 1990s. Until recently, this field was dominated in the English-speaking world by North American publications, the most significant of which is the work of Frederic Reamer (e.g. Rhodes, 1986; Reamer, 1990, 1999;

4 The term 'ethics boom' was used by Davis (1999), writing from a North American perspective, referring to the growth of interest in applied ethics. The 'boom' has continued apace during the first decade of the twenty-first century. 
Loewenberg and Dolgoff, 1996; Congress, 1999; Linzer, 1999). This body of work is now growing internationally, with revised and new texts by Australian, British and Irish authors (e.g. Beckett and Maynard, 2005; Banks, 2006; Bowles et al., 2006; Parrott, 2006; Charleton, 2007). The availability of textbooks on social work ethics in languages other than English is difficult to assess, but reports from colleagues internationally suggest a shortage, which is now beginning to be addressed (see Diekmann (2003) for an overview of some relevant European literature). Indeed, there is evidence of an emerging literature on social work ethics published in various languages (e.g. Rouzel, 1997; Linga 's, 1999; Henriksen and Vetlesen, 2001; Martin, 2001; Barroco, 2004), although sometimes this comprises translations of existing English-language publications (Banks, 1997, 1999; Mach-Zagel and Nøhr, 2007). Specific modules on social work ethics are more frequently being taught on professional qualifying programmes, and attention is being paid to methods and approaches to learning and teaching in this area (e.g. Reamer and Abramson, 1982; Black et al., 2002; Banks and Nøhr, 2003; Banks, 2005; Gray and Gibbon, 2007).

We are also seeing a proliferation of new and revised codes of ethics/professional conduct, alongside other ethical guidance and discussion documents produced by professional associations and regulatory bodies (see Banks, 2006, Chapter 4, for an international overview). In countries where social work is a relatively new profession, codes of ethics and procedures for regulation and disciplining of members are being produced for the first time (e.g. Croatia Association of Social Workers, 2004; National Federation of Social Workers in Romania, 2004), whilst significant developments and revisions are in evidence in parts of the world where social work is longer established (e.g. General Social Care Council, 2002; Japanese Association of Social Workers et al., 2004; Canadian Association of Social Workers, 2005). Even in some countries and communities where Western-style codes of conduct based on individual rights and duties seem less relevant, nevertheless codes or declarations of ethics have been developed, sometimes taking the form of a pledge (e.g. South African Black Social Workers' Association, no date; Tata Institute of Social Sciences Social Work Educators' Forum, 1997), or existing codes have been modified to take account of indigenous values, as in New Zealand's bi-cultural and bilingual code of ethics (Aotearoa New Zealand Association of Social Workers, 2008). 


\section{Form: beyond the code and textbook}

Professional ethics is traditionally associated with codes of ethics and textbooks designed for use on professional education programmes. Codes of ethics usually comprise statements of purpose and lists of values, principles, standards and rules for the implementation of principles in practice. Text-books vary, but the majority offer some kind of overview of ethical theories, followed by analysis of difficult cases in terms of principles derived from these theories and/or from codes of ethics and sometimes structured around ethical decision-making models. This approach presents a picture of professional ethics as a rational process involving the application of ethical principles to practice, tackling difficult cases (often described as 'dilemmas') and making decisions. The titles of many of the North American textbooks reflect this focus (Rhodes, 1986; Reamer, 1990; Congress, 1999; Linzer, 1999; Dolgoff et al., 2005). However, this construction of social work ethics is being challenged and broadened, not only by scholarly academic articles, but also by empirical studies of social workers' perceptions, attitudes and actions.

Rossiter et al. (2000), in their study of Canadian social workers, report that codes of ethics are not used in practice and practitioners are often only dimly aware of their existence. Similarly, they did not find social workers using ethical decision-making models. This is not a surprising finding. For, in many cases, there is no time for the professional to consult a step-by-step model. Furthermore, despite the textbook rhetoric, these models are not designed to be used on a daily basis. They are mainly a way of encouraging students (often in a classroom or supervision setting) to reason and reflect systematically on ethical issues in practice, some aspects of which may then become intuitive or 'second nature' as they practise social work. There is, however, a surprisingly large body of literature focusing on the development, perfection and use of such decision-making models, which inevitably contributes to the construction of a particular kind of discourse about social work ethics (for recent thinking on ethical decision making in social work, see McAuliffe and Chenoweth, 2007; Harrington and Dolgoff, 2008).

For our purposes here, the interesting feature of the study undertaken by Rossiter et al. (2000) is that it comprises empirical research designed to explore and describe how practitioners conceptualize and tackle ethical issues in their day-to-day practice and uses this to critique 'textbook' accounts of ethics. It falls into the category of what philosophers call 'descriptive' or 'empirical' ethics (describing 
people's ethical values, beliefs and actions), as opposed to meta-ethics (conceptual analysis of ethical concepts such as 'rights', 'responsibilities', 'professional integrity') or normative ethics (prescribing what people should do in terms of ethical principles, rules and specific actions).

The role and validity of 'empirical ethics', and how, if at all, it relates to what has traditionally been conceived of as 'philosophical ethics', is an area of debate within moral philosophy and other fields of professional ethics (Hope, 1999; Widdershoven and Van Der Scheer, 2004; Smajdov et al., 2008). The issues are complex and would benefit from further attention in relation to social work. This is particularly important, as empirical studies with a focus on aspects of social work ethics are growing (for recent examples, see Banks, 2004, pp. 125-78; McAuliffe, 2005; Strom-Gottfried, 2006; Jawad, 2007; McLaren, 2007) and look set to expand as empirical research in social work grows and a number of doctoral students are choosing research topics related to social work ethics.

Hitherto, there have been few specialist research monographs or advanced texts on aspects of social work ethics (either theoretically or empirically based). Baptista's (1998) specialist book in Portuguese on the relevance of the moral philosophy of Levinas for social education work is one example. Books by Clark (2000), Banks (2004) and Hugman (2005) could be regarded as advanced texts, which, although still general in scope, eschew ethical decision-making models and offer more in-depth critical analysis than introductory textbooks. We might expect and hope for more such contributions in the future as the subject area matures and develops and some of the empirically focused doctoral dissertations are written up for publication. Indeed, this is needed to broaden and deepen social work ethics as a subject area.

\section{Content: taking account of character, care and context}

The most interesting aspect of the thinking and literature on social work ethics is obviously its substantive content, and what this tells us about how the subject area is changing and developing as an academic -professional discourse. Not surprisingly, developments and trends in philosophical ethics, including moral philosophical analyses and studies in cognate areas of professional and applied ethics (particularly medical, nursing and health care ethics), comprise one of the main influences on theoretical approaches to social work ethics. In philosophical ethics, there has 
been a challenge to the dominance of principle-based theories of ethics such as Kantianism (focusing on respect for persons and duty) and consequentialism (focusing on the outcomes of actions). These challenges have come from a revival of virtue ethics (focusing on qualities of character), the development of an ethics of care (focusing on caring relationships), communitarian ethics (focusing on community, responsibility and cooperation) and pluralist, discursive, postmodern or anti-theory approaches to ethics (eschewing single, foundational all-embracing theories). These trends are beginning to be recognized not only in introductory and advanced textbooks that give overviews of relevant theories (Banks, 2004; Hugman, 2005), but also in scholarly articles arguing for the relevance of some of these approaches to social work ethics, particularly virtue ethics (McBeath and Webb, 2002; Clark, 2006; Gray and Lovat, 2007) and the ethics of care, often associated with feminist approaches to ethics (Clifford, 2002; Orme, 2002; Parton, 2003; Graham, 2007). Some of these articles are rather speculative, which is not surprising, given the difficulty of articulating a detailed theoretical approach and showing its relevance to social work practice in a single article. The next stage for social work ethics will be the publication of detailed book-length expositions outlining what, for example, an ethics of care or virtue ethics for social work would look like, along the lines of those developed in health care, social policy and related fields (e.g. Pellegrino and Thomasma, 1993; Kuhse, 1997; Sevenhuisen, 1998; Oakley and Cocking, 2001).

These 'new' approaches to social work ethics pay attention to the situated nature of values and conduct, as embedded in families, relationships, communities and cultures, and take account of commitments to specific others, motives and emotions. They are not based on universally valid, abstract principles, promoting individual freedoms and rights that apply worldwide across all cultures. They may offer more scope, therefore, to respond to the critique of the dominance of Western (particularly Anglo-American) approaches to ethics, which place the individual moral agent in the centre of the picture, rationally weighing up the balance of individual duties and rights. The critique of the cultural imperialism of a particular version of principle-based ethics is not new in social work (see Ejaz, 1991; Silavwe, 1995). Indeed, it is an on-going theme for debate (Yip, 2004; Healy, 2007; Hugman, 2008), especially in relation to the recently created international standards for social work and revised statement of ethical principles (International Federation of Social Workers and International Association of Schools of Social Work, 2004, 2005). The debate about the extent to which there are or should be universally valid ethical principles or criteria for judging character and conduct is particularly pertinent in 
social work. For social work is both an international social movement, concerned to promote social justice across the world, and a situated practice that takes place in a context of national laws, policies and cultures, albeit with increasingly multi-ethnic populations. These issues about universalism, relativism and particularism in ethics are very much alive in moral philosophy, often linked to contemporary social and political concerns around conflicts relating to ethnicity, religion and culture (Browning, 2006; Nussbaum, 2006; Appiah, 2007; Sullivan and Kymlicka, 2007). This suggests that mutual benefit could be gained from more cross-fertilization between moral, political and religious philosophy and social work ethics, especially as social workers are dealing on a daily basis with some of these conflicts and dilemmas at an individual, family and neighbourhood level.

\section{The idea of a situated social work ethics and its relationship to philosophy and politics}

I will end this brief paper with a plea for a further development of the relationship between social work and moral philosophy. Awareness of the links between social work and philosophy is longstanding (Bosanquet, 1916; Pumphrey, 1961: Ragg, 1977; Reamer, 1993; Timms and Watson, 1978). However, this is often confined to the philosophy of social work (political and moral philosophical justifications for and analysis of the rationale and core purpose of social work), rather than philosophy in social work (analyses and discussion of everyday practice in philosophical terms). Although there are several examples of philosophers who have been involved in the writing of books on social work ethics (Downie and Telfer, 1980; Bowles et al., 2006; Charleton, 2007), by and large, moral philosophers have not contributed directly to the debates and literature in social work ethics in the way they have in some other areas of applied and professional ethics, particularly health care and medical ethics. Hence, the field of social work ethics has been constructed largely from within the discipline of social work, with social work authors drawing on and using relevant concepts and theories from moral philosophy (and other areas of professional ethics) as relevant, sometimes in rather piece-meal and simplistic ways.

There is also a need for more conscious linkages between social work ethics and politics. The literature on radical, transformative and anti-oppressive social work has tended to remain relatively separate from the literature on social work ethics. Yet, ethics and politics are intimately connected. Matters of conduct, ethical judgement 
and decision making of individual professionals cannot be abstracted from the political and policy contexts in which they take place. Individual professionals are both influenced by and help create the ethical discourses of the organizations where they work and the policy frameworks within which they practise.

However, there is a tendency in some of the ethics literature to focus on the individual practitioner making difficult ethical decisions in cases that are sometimes constructed in ways that are decontextualized, both from the character and motives of the individual people involved and from the organization, policy, political and social context. This influences how practitioners conceive of and demarcate the domain of 'the ethical' and their perceptions of their ability to act. The focus on difficult cases makes it seem as if 'ethical' issues arise only when a problematic case or difficult dilemma is experienced. As Rossiter et al. (2000) point out, this can result in practitioners regarding the more contextual and policy-related issues in their work (such as hierarchical management structures), which are not framed as 'cases', as to do with 'politics' and therefore not part of their sphere of decision-making influence. It also leads to ignoring the ethical dimensions of other aspects of practice, which are not immediately about action and decision making, such as motives, qualities of character, professional wisdom and moral perception, as precursors to invoking principles or making decisions.

\section{Concluding comments}

Social work ethics is at an interesting stage in its development. Other areas of professional and applied ethics, particularly medical, bio- and health care ethics, are much more well developed, so provide interesting sources of ideas and lessons for social work ethics in its developmental trajectory. Social work ethics, if it continues to broaden its scope beyond traditional professional ethics (focusing on codes and difficult cases) to ethics in professional life (including virtues, relationships of care and the critical moral competence for everyday and transformatory practice), will benefit from more serious engagement with moral, political and religious philosophy. Signs of these developments are emerging, as an overview of the early contributions to the new journal, Ethics and Social Welfare, demonstrates, with articles on existentialist, care, virtue and Habermasian discourse ethics, as well as the role of religion in social work (Banks, 2008). There is also the potential to link some of the sociological ethnographic and discourse analytic studies of everyday social work 
practice (e.g. de Montigny, 1995; Taylor and White, 2000; White and Stancombe, 2003; Hall et al., 2006) with the large body of moral philosophical work on personal integrity, moral distress, moral perception, imagination and the ethics of commitment and resistance.

In conclusion, this brief and partial account of certain aspects of the current literature and thinking in this field suggests that we can look forward to a flourishing and diverse literature on social work ethics over the coming decade. 


\section{References}

Antle, B. and Regehr, C. (2003) 'Beyond individual rights and freedoms: Metaethics in social work research', Social Work, 48(1), pp. 135-44.

Aotearoa New Zealand Association of Social Workers (2008) Code of Ethics, Dunedin, ANZASW.

Appiah, K. A. (2007) Cosmopolitanism: Ethics in a World of Strangers, London, Penguin. Banks, S. (1997) Etica y valores en el trabajo social, Barcelona/Buenos Aires, Ediciones Paidos Iberica.

Banks, S. (1999) Etica e valori nel servizio sociale: Dilemmi morali e operatiri riflessivi nel welfare mix, Trento, Italy, Erickson.

Banks, S. (2004) Ethics, Accountability and the Social Professions, Basingstoke, Palgrave Macmillan.

Banks, S. (2005) 'The ethical practitioner in formation: Issues of courage, competence and commitment', Social Work Education, 24(7), pp. 737-53.

Banks, S. (2006) Ethics and Values in Social Work, 3rd edn, Basingstoke, Palgrave Macmillan.

Banks, S. (2008) 'Ethics and social welfare: The state of play', Ethics and Social Welfare, 2(1), pp. 1-9.

Banks, S. and Nøhr, K. (eds) (2003) Teaching Practical Ethics for the Social Professions, Copenhagen, FESET.

Baptista, I. (1998) Ética e Educação, Porto, Portucalense.

Barroco, M. (2004) Etica y Servicio Social: Fundamentos Ontológicos, São Paulo, Brazil, Biblioteca Latinoamericana de Servicio Social.

Beckett, C. and Maynard, A. (2005) Values and Ethics in Social Work: An Introduction, London, Sage.

Black, P., Congress, E. and Strom-Gottfried, K. (eds) (2002) Teaching Social Work Values and Ethics: A Curriculum Resource, Alexandra, VA, Council on Social Work Education.

Bosanquet, B. (1916) 'The philosophy of casework', Charity Organisation Review, 39(March), pp. 117-33.

Bowles, W., Collingridge, M., Curry, S. and Valentine, B. (2006) Ethical Practice in Social Work: An Applied Approach, Crow's Nest, New South Wales, Allen and Unwin. 
Browning, D. (ed.) (2006) Universalism vs. Relativism: Making Moral Judgements in a Changing, Pluralistic, and Threatening World, Lanham, MD, Rowman and Littlefield.

Canadian Association of Social Workers (2005) Code of Ethics, Ottawa, CASW.

Charleton, M. (2007) Ethics for Social Care in Ireland: Philosophy and Practice, Dublin, Gill and Macmillan.

Clark, C. (2000) Social Work Ethics: Politics, Principles and Practice, Basingstoke, Macmillan.

Clark, C. (2006) 'Moral character in social work', British Journal of Social Work, 36, pp. 75-89.

Clifford, D. (2002) 'Resolving uncertainties? The contribution of some recent feminist ethical theory to the social professions', European Journal of Social Work, 5(1), pp. 31-41.

Congress, E. (1999) Social Work Values and Ethics: Identifying and Resolving Professional Dilemmas, Chicago, Nelson -Hall.

Croatia Association of Social Workers (2004) Etic ki Kodeks Socijalnih Radnika, Zagreb, Croatia Association of Social Workers.

Davis, M. (1999) Ethics and the University, London, Routledge.

D'Cruz, H. and Jones, M. (2004) Social Work Research: Ethical and Political Contexts, London, Sage.

de Montigny, G. (1995) Social Working: An Ethnography of Front-Line Practice, Toronto, University of Toronto Press.

Diekmann, W. (2003) 'Some useful literature for teaching professional ethics', in Banks, S. and Nohr, K. (eds), Teaching Practical Ethics for the Social Professions, Copenhagen, FESET, pp. 159-67.

Dolgoff, R., Loewenberg, F. and Harrington, D. (2005) Ethical Decisions for Social Work Practice, Belmont, CA, Brooks Cole.

Downie, R. and Telfer, E. (1980) Caring and Curing, London, Methuen.

Ejaz, F. K. (1991) 'Self-determination: Lessons to be learned from social work practice in India', British Journal of Social Work, 21, pp. 127-42.

General Social Care Council (2002) Codes of Practice for Social Care Workers and Employers, London, GSCC, available online at www.gscc.org.uk

Graham, M. (2007) 'The ethics of care, black women and the social professions: Implications of a new analysis', Ethics and Social Welfare, 1(2), pp. 194-207.

Gray, M. and Gibbon, J. (2007) 'There are no answers, only choices: Teaching ethical decision making in social work', Australian Social Work, 60(2), pp. 222-38. 
Gray, M. and Lovat, T. (2007) 'Horse and carriage: Why Habermas's discourse ethics gives virtue a praxis in social work', Ethics and Social Welfare, 1(3), pp. 310-28.

Hall, C., Slembrouck, S. and Sarangi, S. (2006) Language Practices in Social Work: Categorisation and Accountability in Child Welfare, London, Routledge.

Harrington, D. and Dolgoff, R. (2008) 'Hierarchies of ethical principles for ethical decision making in social work', Ethics and Social Welfare, 2(2), pp. 183-96.

Healy, L. (2007) 'Universalism and cultural relativism in social work ethics', International Social Work, 50(1), pp. 11-26.

Henriksen, J. O. and Vetlesen, A. (2001) Etik i arbete med manniskor, Lund, Sweden, Studentlittertur.

Hope, T. (1999) 'Empirical medical ethics', Journal of Medical Ethics, 25, pp. 219-20. Hugman, R. (2005) New Approaches in Ethics for the Caring Professions, Basingstoke and New York, Palgrave Macmillan.

Hugman, R. (2008) 'Ethics in a world of difference', Ethics and Social Welfare, 2(2), pp. 118-32.

International Federation of Social Workers and International Association of Schools of Social Work (2004) Ethics in Social Work, Statement of Principles, Berne, IFSW and IASSW, available online at www.ifsw.org

International Federation of Social Workers and International Association of Schools of Social Work (2005) Global Standards for Social Work Education, Berne, IFSW and IASSW, available online at www.ifsw.org

Japanese Association of Social Workers, Japanese Association of Social Workers in Health, Japanese Association of Certified Social Workers and Japanese Association of Psychiatric Social Workers (2004) Code of Ethics of Social Workers, Tokyo, Joint Committee on Ethics, JASW et al.

Jawad, R. (2007) 'Human ethics and welfare particularism: An exploration of the social welfare regime in Lebanon', Ethics and Social Welfare, 1(2), pp. 123-46.

Kuhse, H. (1997) Caring: Nurses, Women and Ethics, Oxford, Blackwell.

Linga ${ }^{\circ}$, L. (1999) Etik for social-og sundhedsarbejdere: En grundbog, Copenhagen, Hans Reitzels Forlag.

Linzer, N. (1999) Resolving Ethical Dilemmas for Social Work Practice, Needham Heights, MA, Allyn and Bacon.

Loewenberg, F. and Dolgoff, R. (1996) Ethical Decisions for Social Work Practice, Itasca, IL, F.E. Peacock.

Mach-Zagel, R. and Nøhr, K. (eds) (2007) Etiske dilemmaer i paedagogisk arbejde, Copenhagen, Hans Reitzels Forlag. 
Martin, E. (2001) Sozialpadagogische Berufsethik. Auf der Suche nach dem richtigen Handeln, Weinhem, Germany, Juventa.

McAuliffe, D. (2005) 'I'm still standing: Impacts and consequences of ethical dilemmas in direct practice', Journal of Social Work Ethics and Values, 2(1), available online at www.socialworker.com/jswve/content/blogcategory/10/34.

McAuliffe, D. and Chenoweth, L. (2007) 'Leave no stone unturned: The inclusive model of ethical decision-making', Ethics and Social Welfare, 2(1), pp. 38-49.

McBeath, G. and Webb, S. (2002) 'Virtue ethics and social work: Being lucky, realistic, and not doing one's duty', British Journal of Social Work, 32, pp. 1015-36.

McLaren, H. (2007) 'Exploring the ethics of forewarning: Social workers, confidentiality and potential child abuse disclosures', Ethics and Social Welfare, 1(1), pp. 22-40.

National Federation of Social Workers in Romania (2004) Ethical Code of the Profession of Social Worker, Mamamures, National Federation of Social Workers in Romania.

Nussbaum, M. (2006) Frontiers of Justice, Cambridge, MA, Belnap/Harvard University Press.

Oakley, J. and Cocking, D. (2001) Virtue Ethics and Professional Roles, Cambridge, Cambridge University Press.

Orme, J. (2002) 'Social work, gender, care and justice', British Journal of Social Work, 32(6), pp. 799-814.

Parrott, L. (2006) Values and Ethics in Social Work Practice, Exeter, Learning Matters. Parton, N. (2003) 'Rethinking professional practice: The contributions of social constructionism and the feminist "ethics of care"', British Journal of Social Work, 33, pp. 1-16.

Pellegrino, E. and Thomasma, D. (1993) The Virtues in Medical Practice, New York, Oxford University Press.

Pumphrey, R. (1961) The Heritage of American Social Work: Readings in its Philosophical and Institutional Development, New York, Columbia University Press.

Ragg, N. (1977) People not Cases: A Philosophical Approach to Social Work, London, Routledge and Kegan Paul.

Reamer, F. (1990) Ethical Dilemmas in Social Service, 2nd edn, New York, Columbia University Press.

Reamer, F. (1993) The Philosophical Foundations of Social Work, New York, Columbia University Press. 
Reamer, F. (1999) Social Work Values and Ethics, 2nd edn, New York, Columbia University Press.

Reamer, F. (2006) Social Work Values and Ethics, 3rd edn, New York, Columbia University Press.

Reamer, F. and Abramson, M. (1982) The Teaching of Social Work Ethics, Hastings-on-Hudson, New York, Hastings Center.

Rhodes, M. (1986) Ethical Dilemmas in Social Work Practice, Boston, MA, Routledge and Kegan Paul.

Rossiter, A., Prilleltensky, I. and Walsh-Bowers, R. (2000) 'A postmodern perspective on professional ethics', in Fawcett, B., Featherstone, B., Fook, J. and Rossiter, A. (eds), Postmodern Feminist Perspectives: Practice and Research in Social Work, London, Routledge, pp. 83-103.

Rouzel, J. (1997) Le travail d'éducateur spécialisé: éthique et pratique, Paris, Dunod.

Sevenhuisen, S. (1998) Citizenship and the Ethics of Care: Feminist Considerations on Justice, Morality and Politics, London, Routledge.

Silavwe, G. W. (1995) 'The need for a new social work perspective in an African setting: The case of social casework in Zambia', British Journal of Social Work, 25, pp. 71-84.

Smajdov, A., Ives, J., Baldock, E. and Langlois, A. (2008) 'Getting from the ethical to the empirical and back again: The danger of getting it wrong, and the possibilities for getting it right', Health Care Analysis, 16(1), pp. 7-16.

South African Black Social Workers' Association (no date, received 1999) Code of Ethics, South Africa, SABSWA.

Strom-Gottfried, K. (2006) 'Ethical decision-making among hospital social workers', Journal of Social Work Ethics and Values, 3(1), available online at www.socialworker. com/jswve/content/new/27/44.

Sullivan, W. and Kymlicka, W. (eds) (2007) The Globalisation of Ethics, Cambridge, Cambridge University Press.

Tata Institute of Social Sciences Social Work Educators' Forum (1997) ‘Declaration of ethics for professional social workers', The Indian Journal of Social Work, 58(2), pp. 335-41.

Taylor, C. and White, S. (2000) Practising Reflexivity in Health and Welfare, Buckingham, Open University Press.

Timms, N. and Watson, D. (eds) (1978) Philosophy in Social Work, London, Routledge and Kegan Paul. 
White, S. and Stancombe, J. (2003) Clinical Judgement in the Health and Welfare Professions: Extending the Evidence Base, Maidenhead, Open University Press.

Widdershoven, G. and Van Der Scheer, L. (2004) 'Integrated empirical ethics: Loss of normativity?', Medicine, Health Care and Philosophy, 7(1), pp. 71-9.

Yip, K.-S. (2004) 'A Chinese cultural critique of the global qualifying standards for social work education', Social Work Education, 23(5), pp. 597-612. 